\title{
TIPE NEGARA ABAD PERTENGAHAN DAN EKSISTENSINYA
}

\author{
Nama Mahasiswa: Zulfadhli \\ Email : zulfadhliamin133@gmail.com \\ No BP : 2110003600059 \\ Perguruan Tinggi: Universitas Ekasakti
}

\section{A. PENDAHULUAN}

Tipe negara abad kejayaan ini telah menjadi sejarah karena mempunyai cirinya tersendiri. Kita bisa mengulas sebuah konsep bahwa negara itu adalah sistem yang betul- betul berkuasa terhadap kehidupan seluruh yang ada di dalamnya demi mesejahterakan rakyatnya. Tipe negara abad pertengahan pada zaman ini dikenal dengan hukum pedata dan diterima sebagai dasar-dasar bernegara pada pertengahan. Tipe negara dapat dibagi sesuai dengan ciri pokok yang dominan dari suatu negara dalam sejarah.

Tipe Negara abad pertengahan ialah feodalistis berdasarkan hak perseorangan yang mutlak. Tetapi dalam perkembangannya hak milik tidak lagi mutlak, tetapi hak milik mempunyai kewajiban untuk mengabdi kepada kepentingan umum.Sejarah telah mencatat bahwa setiap zaman mempunyai pemikiran-pemikiran yang berbeda dan tokoh- tokoh yang berbeda mengenai cerita ketatanegaraan.

Abad pertengahan merupakan abad setelah jatuhnya imperium Romawi, yang sejalan dengan runtuhnya ketatanegaraan sehingga kekuasaan agama Kristen makin berkembang dan menggantikan sistem ketatanegaraan menurut gereja.

Teori tipe-tipe negara bermaksud membahas tentang penggolongan negara didasarkan pada ciri-ciri khas yang ada pada suatu negara.

Negara adalah suatu organisasi atau asosiasi wilayah yang memiliki kekuatan individu dan daerah yang mengatur setiap kumpulan manusia - manusia yang berbeda dibawah 
suatu pemerintahan yang sama dengan terapan sistem hukum.

Bentuk atau Tipe negara adalah merupakan batas antara peninjauan secara sosiologis dan peninjauan secara yuridis mengenai negara. Peninjauan secara sosiologis jika negara dilihat secara keseluruhan (ganzhit) tanpa melihat strukturnya, sedangkan secara yuridis jika negaralpeninjauan dilihat dari strukturnya.

\section{B. PEMBAHASAN}

Abad Pertengahan dalam sejarah Eropa berlangsung dari abad ke-5 sampai abad ke-15 Masehi. Abad Pertengahan bermula sejak runtuhnya Kekaisaran Romawi Barat dan masih berlanjut manakala Eropa mulai memasuki Abad Pembaharuan dan Abad Penjelajahan. Sejarah Dunia Barat secara tradisional dibagi menjadi tiga kurun waktu, yakni Abad Kuno, Abad Pertengahan, dan Zaman Modern. Dengan kata lain, Abad Pertengahan adalah kurun waktu peralihan dari Abad Kuno ke Zaman Modern. Abad Pertengahan masih terbagi lagi menjadi tiga kurun waktu, yakni Awal Abad Pertengahan, Puncak Abad Pertengahan, dan Akhir Abad Pertengahan.

1. Tipe Negara Abad Pertangahan, ciri-ciri:

a. DUALISME, adanya perlawanan antarapenguasa

b. FEODALISME, penguasa berdasarkan hak milik

c. PERLAWANAN ANTARA GEREJA \& NEGARA, sehingga lahir TEORI TEOKRATIS \& TEORI SECULARISME yang pemerintahanya meliputi urusan keagamaan \& urusan kenegaraan

d. STANDENSTAATS, sifat negara berdasarkan lapisan2 yg ada dalam masyarakat

2. Awal Abad Pertengahan

Masyarakat-masyarakat baru 
Tatanan politik Eropa Barat berubah seiring tamatnya riwayat Kekaisaran Romawi bersatu. Meskipun pergerakan-pergerakan suku-suku bangsa yang terjadi kala itu lazimnya digambarkan sebagai "invasi", pergerakan-pergerakan ini bukan semata-mata merupakan pergerakan militer melainkan juga gerak perpindahan seluruh warga suku-suku bangsa itu ke dalam wilayah kekaisaran. Pergerakanpergerakan semacam ini dileluasakan oleh penolakan para petinggi Romawi di wilayah barat untuk menyokong angkatan bersenjata maupun untuk membayar pajak-pajak yang mampu memberdayakan angkatan bersenjata guna membendung arus migrasi. Para kaisar abad ke-5 kerap dikendalikan oleh orang-orang kuat dari kalangan militer seperti Stiliko (wafat 408), Esius (wafat 454), Aspar (wafat 471),

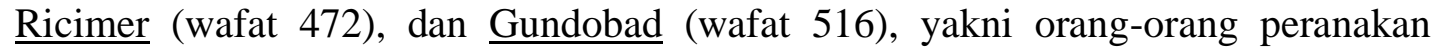
Romawi atau sama sekali tidak berdarah Romawi. Meskipun wilayah barat tidak lagi diperintah oleh kaisar-kaisar, banyak di antara raja-raja yang memerintah di wilayah itu masih terhitung kerabat mereka. Perkawinan campur antara wangsawangsa penguasa yang baru dan kaum bangsawan Romawi sudah lumrah terjadi.Akibatnya, budaya asli Romawi pun mulai bercampur dengan adat istiadat suku-suku yang menduduki wilayah barat, termasuk penyelenggaraan sidang- sidang rakyat yang semakin memberi ruang bagi warga suku laki-laki yang merdeka untuk urun rembuk dalam perkara-perkara politik, berbeda dari kebiasaan yang dulu berlaku di negeri Romawi. Barang-barang peninggalan orang Romawi sering kali serupa dengan barang-barang peninggalan suku-suku yang menduduki wilayah barat, dan barang-barang buatan suku-suku itu sering kali dibuat dengan cara meniru bentuk barang-barang buatan Romawi.Sebagian besar budaya tulis dan ilmiah di kerajaan-kerajaan baru itu juga didasarkan pada tradisi-tradisi intelektual Romawi. 
Salah satu perbedaan penting kerajaan- kerajaan baru ini dari Kekaisaran Romawi adalah kian susutnya penerimaan pajak sebagai sumber pendapatan pemerintah. Banyak dari kerajaan-kerajaan baru ini tidak lagi menafkahi angkatan bersenjata mereka dengan menggunakan dana penerimaan pajak, tetapi dengan anugerah lahan atau hak sewa lahan. Dengan demikian, penerimaan pajak dalam jumlah besar sudah tidak diperlukan lagi, sehingga tatanan perpajakan Romawi akhirnya ditinggalkan. Perang menjadi sesuatu yang lumrah, baik perang antarkerajaan maupun perang di dalam suatu kerajaan. Angka perbudakan menurun karena pasokan berkurang, dan masyarakat pun semakin bercorak pedesaan.

\section{Puncak Abad Pertengahan}

\section{Masyarakat dan perekonomian}

Puncak Abad Pertengahan adalah kurun waktu terjadinya lonjakan populasi secara besar- besaran. Populasi Eropa diperkirakan melonjak dari 35 juta jiwa menjadi 80 juta jiwa antara tahun 1000 dan 1347. Meskipun penyebabnya belum diketahui secara pasti, diduga lonjakan populasi ini disebabkan oleh semakin baiknya tata cara bercocok tanam, berkurangnya perbudakan, iklim yang lebih baik, maupun ketiadaan invasi. Sebanyakbanyaknya $90 \%$ populasi Eropa masih terdiri atas kaum tani yang bermukim di desadesa. Banyak di antaranya tidak lagi mendiami lahan-lahan terpencil, tetapi sudah hidup bersama-sama dalam komunitas-komunitas kecil yang disebut desa atau tanah pertuanan. Kaum tani sering kali menjadi kawula kaum ningrat pemilik tanah pertuanan (bahasa Inggris: manor), dan membayar sewa lahan atau memberikan berbagai macam bentuk pelayanan kepada majikan- majikan ningrat mereka. Tatanan semacam ini disebut manorialisme. Meskipun demikian, masih ada segelintir petani merdeka (bukan kawula tuan tanah) pada kurun waktu ini maupun sesudahnya. Petani-petani merdeka semacam 
ini lebih banyak terdapat di kawasan selatan daripada di kawasan utara Eropa. Praktik babad atau meneroka lahan baru untuk digarap dengan cara menawarkan insentif kepada petani yang bersedia menempatinya, juga turut berdampak pada lonjakan populasi.

\section{Munculnya kekuasaan negara}

Puncak Abad Pertengahan adalah kurun waktu formatif dalam sejarah negara modern di Dunia Barat. Raja-raja di Prancis, Inggris, dan Spanyol memperkukuh kekuatan mereka, dan membentuk lembaga-lembaga pemerintahan yang terus bertahan dalam waktu yang sangat lama. Kerajaan-kerajaan baru, seperti Hongaria dan Polandia, menjadi kekuatan-kekuatan utama di kawasan tengah Eropa setelah menerima agama Kristen. Orang Magyar menetap di Hongaria sekitar tahun 900 di bawah pimpinan Raja Árpád (wafat sekitar 907) setelah beberapa kali melancarkan invasi pada abad ke-9. Lembaga kepausan, yang sudah lama terpikat pada ideologi kemerdekaan dari raja-raja sekuler, untuk pertama kali dalam sejarahnya menyatakan diri sebagai penguasa duniawi atas seluruh Dunia Kristen. Monarki kepausan mencapai puncak kejayaannya pada awal abad ke-13 di bawah kepemimpinan Paus Inosensius III (menjabat 1198-1216). Perang Salib Utara dan pergerakan kerajaan-kerajaan dan tarekat-tarekat militer Kristen ke daerah-daerah kaum penganut kepercayaan leluhur di kawasan Laut Baltik dan kawasan timur laut Finlandia mengakibatkan terjadinya asimilasi paksa sejumlah besar suku bangsa pribumi setempat ke dalam kebudayaan Eropa.

\section{Akhir Abad Pertengahan}

\section{Perang, Bencana Kelaparan, Dan Wabah Penyakit}

Tahun-tahun permulaan abad ke-14 ditandai oleh bencana-bencana kelaparan, yang memuncak pada Bencana Kelaparan Besar 1315-1317. Salah satu penyebab Bencana Kelaparan Besar ini adalah transisi peralihan yang berlangsung lambat dari 
Periode Suhu Hangat Abad Pertengahan ke Zaman Es Kecil, sehingga masyarakat rentan tertimpa bencana kelaparan bilamana cuaca memburuk dan mengakibatkan gagal panen. Kurun waktu 1313-1314 dan 1317-1321 adalah kurun waktu turunnya hujan deras di seluruh Eropa, yang mengakibatkan gagal panen di mana-mana. Perubahan iklim - yang mengakibatkan penurunan suhu tahunan rata-rata di Eropa pada abad ke-14 — terjadi bersamaan dengan merosotnya perekonomian.

Segala kemelut ini disusul pada 1347 oleh malapetaka Maut Hitam, wabah penyakit menular yang berjangkit ke seluruh pelosok Eropa dalam tiga tahun berikutnya. Jumlah korban tewas diperkirakan mencapai 35 juta jiwa di Eropa, yakni sekitar sepertiga dari keseluruhan populasi Eropa. Dampak dari wabah ini lebih terasa di kota-kota karena tingkat kepadatan penduduknya yang lebih tinggi. Kelangkaan populasi mengakibatkan tanah-tanah yang luas hanya didiami segelintir orang, dan ladang-ladang menjadi terbengkalai di beberapa tempat. Upah meningkat karena para tuan tanah berusaha memikat tenaga kerja yang sudah menyusut jumlahnya itu agar bersedia menggarap lahan-lahan mereka. Masalah selanjutnya adalah menurunnya sewa tanah dan merosotnya permintaan akan bahan pangan, yang memangkas jumlah pendapatan dari sektor pertanian. Kaum buruh di kota-kota juga mulai merasa patut diberi upah yang lebih besar, dan pemberontakan rakyat merebak di seluruh Eropa, antara lain pemberontakan jacquerie di Prancis, pemberontakan kaum tani di Inggris, pemberontakan di kota Firenze di Italia, serta pemberontakan di kota Gent dan kota Brugge di Flandria. Trauma yang ditimbulkan oleh wabah ini menyebabkan kesalehan masyarakat meningkat di seluruh Eropa, yang diwujudkan melalui pembentukan lembaga- lembaga amal yang baru, praktik bermatiraga kaum Flagelan, dan tindakan 
mengambinghitamkan umat Yahudi. Keadaan kian runyam ketika Maut Hitam kembali berjangkit sepanjang sisa kurun waktu abad ke-14; wabah ini masih terus menghantam Eropa secara berkala sepanjang sisa kurun waktu Abad Pertengahan.

\section{Masyarakat dan ekonomi}

Masyarakat di seluruh Eropa terguncang oleh perubahan-perubahan besar yang diakibatkan oleh malapetaka Maut Hitam. Lahan-lahan yang kurang produktif ditelantarkan, karena orang-orang yang masih hidup kini mampu mendapatkan lahanlahan lain yang lebih subur.Meskipun kian berkurang di kawasan barat Eropa, praktik perhambaan kaum tani justru menjadi semakin lumrah di kawasan timur Eropa, karena tuan-tuan tanah memaksa para penyewa lahan yang sebelumnya merdeka untuk menjadi hamba sahaya mereka.Sebagian besar kaum tani di kawasan barat Eropa berhasil mengganti kewajiban kerja bakti bagi majikan-majikan mereka menjadi pembayaran sewa lahan secara tunai. Persentase kaum tani yang menghamba pada tuan tanah menyusut dari 90\% sampai mendekati $50 \%$ pada akhir kurun waktu ini.Tuan-tuan tanah pun menjadi semakin sadar akan kepentingankepentingan bersama dengan tuan-tuan tanah lainnya, dan akhirnya bersatu untuk menuntut anugerah hak-hak istimewa dari pemerintah. Tuntutan ini menjadi salah satu faktor yang mendorong pemerintah untuk berusaha mengundang-undangan aturan-aturan yang bertujuan memulihkan keadaan ekonomi seperti sediakala sebelum berjangkitnya Maut Hitam.Orang-orang di luar kalangan rohaniwan semakin lama semakin terpelajar, dan masyarakat perkotaan mulai ikut-ikutan meminati akhlak bahaduri sebagaimana kaum bangsawan.

\section{Kebangkitan Negara}

Negara-negara bangsa yang kuat berlandaskan kekuasaan raja-raja mengalami 
kebangkitan di seluruh Eropa pada Akhir Abad Pertengahan, terutama di Inggris, Prancis, dan kerajaan-kerajaan Kristen di Jazirah Iberia, yakni Kerajaan Aragon, Kerajaan Kastila, dan Kerajaan Portugal. Sengketa-sengketa berkepanjangan yang terjadi kala itu memperkuat kendali raja-raja atas kerajaan-kerajaan mereka dan sangat menyulitkan kaum tani. Raja-raja diuntungkan dari perang yang memperbesar kewenangan hukum raja dan menambah luas tanah-tanah yang mereka kuasai secara langsung. Kebutuhan pendanaan perang mendorong diciptakannya cara-cara memungut pajak yang lebih efektif dan efisien, dan tarif pajak sering kali dinaikkan. Adanya persyaratan meminta persetujuan para wajib pajak memungkinkan badanbadan perwakilan rakyat seperti Parlemen Inggris dan États Généraux Prancis untuk mendapatkan kuasa dan kewenangan. 



\section{PENUTUP}

Teori tipe-tipe negara bermaksud membahas tentang penggolongan negara didasarkan pada ciri-ciri khas yang ada pada suatu negara. Berdasarkan sejarah teori kenegaraan

Ciri khas tipe negara pada abad pertengahan adalah :

1. Teokrati

2. Feodalis

3. Dualisme dalam bernegara, yaitu dualisme (pertentangan) antara:

a. Penguasa dengan rakyat.

b. Pemilik dan penyewa tanah (yang menyebabkan timbulnya feodalisme)

c. Negarawan dan gerejawan (yang menimbulkan sekularisme).

Akibat adanya dualisme ini timbul keinginan dari rakyat untuk membatasi hak dan kewajiban raja dan rakyat. Hal ini dikemukakan oleh aliranmonarchomachen (golongan anti raja yang mutlak). Perjanjian yang mereka sepakati diletakkan dalam leges fundamentalis yang berlaku sebagai undang-undang. 


\section{DAFTAR PUSTAKA}

Darmini Roza dan Laurensius Arliman S, Peran Pemerintah Daerah Di Dalam Melindungi Hak Anak Di Indonesia, Masalah-Masalah Hukum, Volume 47, Nomor 1, 2018. https://doi.org/10.14710/mmh.47.1.2018.10-21

Laurensius Arliman S, Peranan Metodologi Penelitian Hukum di Dalam Perkembangan Ilmu Hukum di Indonesia, Soumatera Law Review, Volume 1, Nomor 1, 201. http://doi.org/10.22216/soumlaw.v1i1.3346.

Laurensius Arliman S, Peran Badan Permusyawaratan Desa di Dalam Pembangunan Desa dan Pengawasan Keuangan Desa, Padjadjaran Journal of Law, Volume 4, Nomor 3, 2017. https://doi.org/10.15408/jch.v4i2.3433.

Laurensius Arliman S, Penanaman Modal Asing Di Sumatera Barat Berdasarkan Undang- Undang Nomor 25 Tahun 2007 Tentang Penanaman Modal, Supremasi Hukum, Volume 1, Nomor 1, 2018. http://dx.doi.org/10.36441/hukum.v1i01.102 .

Laurensius Arliman S, Memperkuat Kearifan Lokal Untuk Menangkal Intoleransi Umat Beragama Di Indonesia, Ensiklopedia of Journal, Volume 1, Nomor 1, 2018, https://doi.org/10.33559/eoj.v1i1.18.

Laurensius Arliman S, Perkawinan Antar Negara Di Indonesia Berdasarkan Hukum Perdata Internasional, Kertha Patrika, Volume 39, Nomor 3, 2017,https://doi.org/10.24843/KP.2017.v39.i03.p03.

Laurensius Arliman S, Partisipasi Masyarakat Di Dalam Pengelolaan Uang Desa PascaUndang-Undang Nomor 6 Tahun 2014 Tentang Desa, Jurnal Arena Hukum, Volume 12, Nomor 2, 2019, https://doi.org/10.21776/ub.arenahukum.2019.01202.5.

Laurensius Arliman S, Mewujudkan Penegakan Hukum Yang Baik Di Negara Hukum Indonesia, Dialogica Jurnalica, Volume 11, Nomor 1, 2019, https://doi.org/10.28932/di.v11i1.1831.

Laurensius Arliman S, Mediasi Melalui Pendekatan Mufakat Sebagai Lembaga Alternatif Penyelesaian Sengketa Untuk Mendukung Pembangunan Ekonomi Nasional, UIR Law Review, Volume 2, Nomor 2, 2018, https://doi.org/10.25299/uirlrev.2018.vol2(02).1587

Laurensius Arliman S, Peranan Filsafat Hukum Dalam Perlindungan Hak Anak Yang Berkelanjutan Sebagai Bagian Dari Hak Asasi Manusia, Doctrinal, Volume 1, Nomor 2,2016.

Laurensius Arliman S, Ni Putu Eka Dewi, Protection of Children and Women's Rights in Indonesia through International Regulation Ratification, Journal of Innovation, Creativity and Change Volume 15, Nomor 6, 2021.

Laurensius Arliman S, Gagalnya Perlindungan Anak Sebagai Salah Satu Bagian Dari Hak Asasi Manusia Oleh Orang Tua Ditinjau Dari Mazhab Utilitarianisme, Jurnal Yuridis, Volume 3, Nomor 2, 2016, http://dx.doi.org/10.35586/.v3i2.180.

Laurensius Arliman S, Tantangan Pendidikan Kewarganegaraan Pada Revolusi 4.0, Jurnal Ensiklopedia Sosial Review, Volume 2, Nomor 3, 2020.. 
